\title{
Pathogenic Roles of Tumor Necrosis Factor Receptor p55-Mediated Signals in Dimethylnitrosamine-Induced Murine Liver Fibrosis
}

\author{
Kazuya Kitamura, Yasunari Nakamoto, Mariko Akiyama, Chifumi Fujii, \\ Toshikazu Kondo, Kenichi Kobayashi, Shuichi Kaneko, and Naofumi Mukaida
}

Department of Gastroenterology (K. Kitamura, YN, K. Kobayahsi, SK), Graduate School of Medicinal Sciences, Division of Molecular Bioregulation (K. Kitamura, MA, CF, NM), Cancer Research Institute, and Division of Environmental Science, Forensic and Social Environmental Medicine (TK), Graduate School of Medicinal Sciences, Kanazawa University, Kanazawa, Japan

SUMMARY: TNF- $\alpha$ has pleiotropic functions, but its role in liver fibrosis has not yet been clarified. To understand the pathophysiologic role of the TNF- $\alpha$ /TNF receptor (TNFR) p55 signals in liver fibrosis, $10 \mathrm{mg} / \mathrm{kg}$ of dimethylnitrosamine, a specific hepatotoxicant, was administered twice a week into the peritoneal cavity of both TNFRp55 knock-out (KO) and wild-type mice, and the severity of fibrosis was monitored histologically and biochemically. In wild-type mice, histologic analysis demonstrated evident fibrotic changes 1 week after the initiation of dimethylnitrosamine administration, consistent with increased liver collagen contents. Concomitantly, the numbers of Kupffer cells and activated hepatic stellate cells (HSCs) were increased in liver tissue. On the contrary, fibrotic changes were attenuated and the numbers of Kupffer cells and HSCs were decreased in TNFRp55-KO mice. Moreover, gene expression of TNF- $\alpha$ and monocyte chemoattractant protein-1, which are involved in Kupffer cell activation or migration, was decreased in the liver of TNFRp55-KO mice. Collectively, TNFRp55-mediated signals may regulate activation of Kupffer cells and HSCs and eventually enhance fibrotic process. (Lab Invest 2002, 82:571-583).

$C$ hronic liver injury frequently causes liver fibrosis, which eventually results in liver cirrhosis, the end-stage of liver disease (Sherlock and Dooley, 1997). Despite many efforts to clarify the pathogenesis of liver fibrosis, the molecular and cellular mechanisms of the disease have not been well elucidated (Friedman, 1993, 2000). Previous studies demonstrated that serum levels of several cytokines and growth factors, including IL-1, IL-6, IL-8, IFN- $\gamma$, transforming growth factor (TGF)- $\beta$, and TNF- $\alpha$ were increased in patients with chronic liver disease and liver cirrhosis (Llorente et al, 1996; Napoli et al, 1994; Tilg et al, 1992). Among these cytokines, the results from animal models have provided evidence that TNF- $\alpha$ plays a crucial role in liver inflammation, hepatocyte regeneration, and apoptosis (Bruccoleri et al, 1997; limuro et al, 1997; Leist et al, 1995; Tsuji et al, 1997; Yamada et al, 1998; Yin et al, 1999). However, its role in liver fibrosis has not yet been clarified.

TNF- $\alpha$ exhibits pleiotropic effects on proinflammatory gene expression, cytotoxicity cascade, cell proliferation, differentiation, and apoptosis (Beutler and

Received January 16, 2002.

This work was supported in part by a grant from the Japanese Ministry of Education, Culture, Sports, Science and Technology.

Address reprint requests to: Dr. Naofumi Mukaida, Department of Molecular Oncology, Cancer Research Institute, Kanazawa University, Takaramachi 13-1, Kanazawa 920-0934, Japan.E-mail: naofumim@kenroku. kanazawa-u.ac.jp
Cerami, 1986; Larrick and Wright, 1990). Biologic activities of TNF- $\alpha$ are mediated by two receptors encoded by two distinct genes, a 55-kd TNF receptor (TNFRp55, TNFR1) and a 75-kd TNF receptor (TNFRp75, TNFR2) (Lewis et al, 1991). TNFRp55 is expressed on almost all somatic cells, whereas TNFRp75 is expressed mainly on leukocytes and endothelial cells. Experiments using a specific antibody or gene-deficient mice indicate that TNFRp55 is the primary signaling receptor for TNF- $\alpha$ on most types of cells (Kanaly et al, 1999; Peschon et al, 1998; Rothe et al, 1993; Tartaglia et al, 1991).

Several lines of evidence indicate that the TNF/ TNFRp55 signal plays crucial roles in several liver disease models. Liver regeneration after partial hepatectomy or CCl4-induced liver injury was severely impaired in the mice treated with anti-TNF antibody or in mice lacking TNFRp55 (Bruccoleri et al, 1997; Yamada et al, 1998; Yamada and Fausto, 1998). These findings implied that the signals through TNFRp55 were necessary for compensatory hepatocyte proliferation after liver damage. In addition, TNF- $\alpha$ has been reported to prevent Fas-mediated hepatocyte apoptosis (Takehara et al, 1998). In contrast, TNF- $\alpha$ is known to induce hepatocyte apoptosis in several murine models in the presence of D-galactosamine, actinomycin D, or $\alpha$-amanitin in a TNFRp55dependent manner, as evidenced by the observations that mice deficient in TNFRp55 were resistant to hepatocyte apoptosis induced by these drugs (Leist et 
al, 1995, 1997). Moreover, alcohol-induced liver injury was attenuated by the administration of a specific antibody against TNF or in TNFRp55 gene ablation (limuro et al, 1997; Yin et al, 1999). Furthermore, soluble TNFR treatment prevented the CCl4-induced acute liver injury in rats (Czaja et al, 1995). Thus, TNF/TNFRp55 signals may exhibit contradictory effects on liver injuries, depending on the types of insults.

To clarify the role of TNF/TNFRp55 signaling in liver fibrosis, we treated wild-type (WT) and TNFRp55 knock-out (KO) mice with dimethylnitrosamine (DMN) to evaluate the fibrotic changes. Here, we demonstrated that liver fibrosis was markedly attenuated in TNFRp55-KO mice compared with WT mice. Moreover, the numbers of Kupffer cells and hepatic stellate cells (HSC) in liver tissues were reduced in TNFRp55-KO mice, suggesting that TNF/TNFRp55 signals are critically involved in Kupffer cell and HSC activation and eventual liver fibrosis.

\section{Results}

\section{Attenuated Liver Inflammation in TNFRp55-KO Mice}

First we performed histologic examination in WT and KO mice before or after DMN treatment. Histologic findings revealed no apparent differences in livers between untreated WT and KO mice as previously described (Tsuji et al, 1997) (Fig. 1, a and d). Mononuclear cell infiltration was observed in perivascular areas of WT mice 1 week after DMN administration (Fig. 1b) and was increased 2 weeks after DMN treatment (data not shown). At 4 weeks after the treatment, the infiltration was still observed and liver tissues were distorted (Fig. 1c). In contrast, mononuclear cell infiltration was barely observed in livers from $\mathrm{KO}$ mice 1 week after DMN administration (Fig. 1e). Moreover, the number of cell infiltrates and the tissue distortion were markedly diminished in KO mice 4 weeks after DMN treatment compared with WT mice (Fig. 1f).
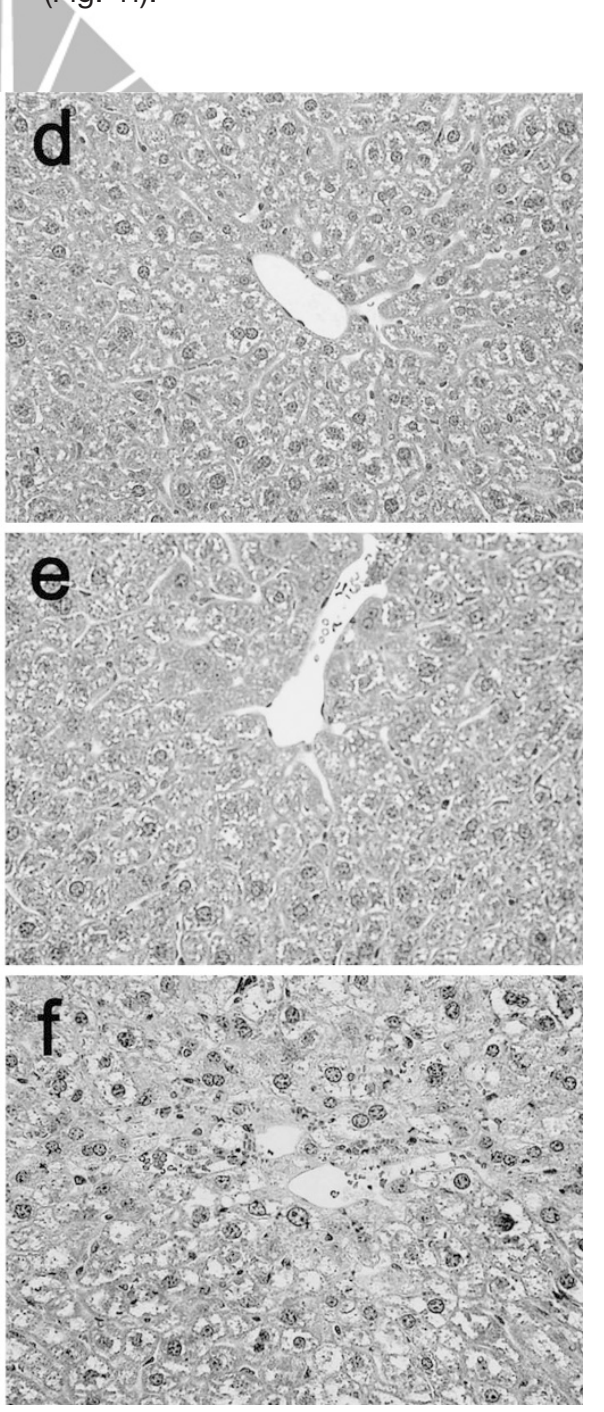

Figure 1.

Histopathologic changes in dimethylnitrosamine (DMN)-treated animals. Liver tissues were obtained from wild-type (WT; left panels) or TNFRp55 knock-out (TNFRp55-KO; right panels) mice before (a and d), 1 week after ( $b$ and e), or 4 weeks after (c and f) the initiation of DMN administration. The sections were stained with hematoxylin-eosin. Representative results from at least three individual animals in each group are shown here. Original magnification, $\times 400$. 
To assess the severity of liver injury in WT and KO mice after DMN administration, we measured serum alanine aminotransferase (ALT) levels. ALT levels were elevated in both WT and KO mice 1 week after DMN administration and decreased gradually thereafter despite continuous DMN administration (Fig. 2). However, there were no significant differences in ALT levels between WT and KO mice at each time point, suggesting that hepatocytes were injured to a similar extent in both WT and KO mice.

To identify the types of infiltrating cells, we performed immunohistochemical analysis using monoclonal antibody for F4/80 antigen, which is a cell surface marker expressed on mouse monocytes/macrophages and Kupffer cells. Before DMN administration, the number of Kupffer cells was slightly but significantly larger in KO mice than in WT mice (Fig. 3, a, d, and g). F4/80-positive cells started to infiltrate into perivascular areas 1 week after DMN administration in WT mice (Fig. 3b), and significantly fewer F4/80-positive cells were observed in livers of KO mice at the same time point (Fig. 3, e and g). The number of $F 4 / 80$-positive cells was progressively increased in WT mice 2 weeks after the initiation of DMN administration and remained at similar levels even at 4 weeks (Fig. 3, c and g). Moreover, the increased Kupffer cells were mainly localized in perivascular areas. In contrast, the number of F4/80-positive cells in livers from KO mice was not increased and remained about one third of the number in WT mice $(p<$ 0.01). Furthermore, only a marginal level of tissue distortion was observed in $\mathrm{KO}$ mice 2 and 4 weeks after the initiation of DMN administration (Fig. 3f). Collectively, these results suggest that TNFRp55mediated signals contribute to the F4/80-positive cell infiltration and the tissue distortion induced by DMN exposure (Fig. 3g).

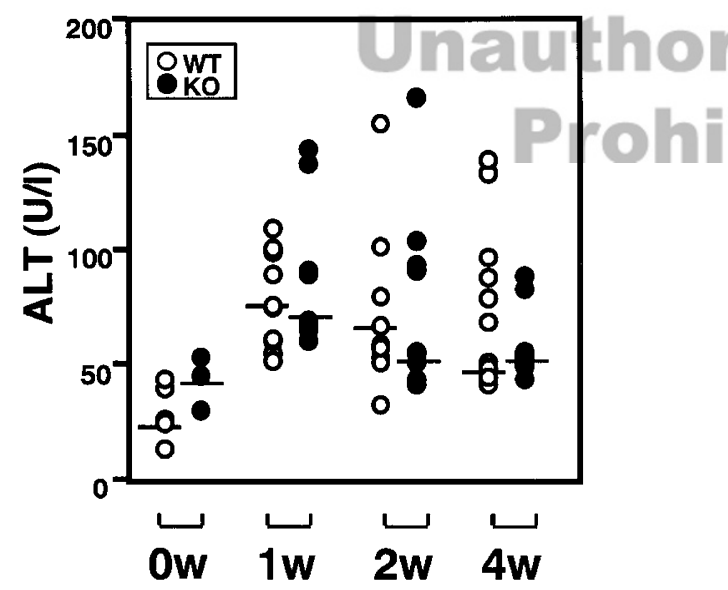

Figure 2.

Changes in serum alanine aminotransferase (ALT) levels. WT (open circles) or TNFRp55-KO (closed circles) mice were intraperitoneally injected twice a week with DMN for the indicated time intervals. Serum ALT levels were determined as described in "Materials and Methods." Each symbol represents the value obtained from one animal, and each bar represents the median of each group.

\section{Decreased Collagen Production in the Livers of TNFRP55-KO Mice}

To evaluate fibrotic changes, we performed Azan staining to detect collagen accumulation. The results of Azan staining revealed collagen accumulation in livers of DMN-treated WT mice after 1 week after DMN administration and became more abundant thereafter. However, collagen accumulation was minimal in $\mathrm{KO}$ mice (Fig. 4, b, c, e, and f). Similarly, as shown in Figure 1, the tissue distortion became evident in WT mice but not in $\mathrm{KO}$ mice 4 weeks after the initiation of DMN administration (Fig. 4, c and f).

We further quantified collagen contents in liver tissues. As shown in Figure 5, collagen levels were similar between both groups before DMN administration. However, collagen levels in WT mice started to increase 1 week after DMN administration and reached statistically higher levels at 4 weeks $p<$ 0.05). In contrast, the collagen contents did not change significantly in $\mathrm{KO}$ mice during the whole course of DMN treatment (Fig. 5). To exclude the possibility that reduced liver collagen contents in $\mathrm{KO}$ mice was a result of accelerated degradation of collagen, we analyzed mRNA expression of matrix metalloproteinase (MMP) and tissue inhibitor of MMP (TIMP). However, there was no significant difference between WT and KO mice in MMP and TIMP gene expression during the whole course of the treatment (Fig. 6). Thus, reduced fibrotic changes in $\mathrm{KO}$ mice can be ascribed to decreased collagen production in the liver tissues:-

\section{Comparison of Cytokine and Growth Factor Gene Expression in the Livers of DMN-Treated Mice}

We next examined intrahepatic gene expression of TNF- $\alpha$, TGF- $\beta$, monocyte chemoattractant protein (MCP)-1, and macrophage (M)-CSF, which are presumed to be involved in Kupffer cell activation, migration, or proliferation. As shown in Fig. 7, A and B, TNF- $\alpha$ mRNA levels were increased after treatment with DMN in WT mice. In contrast, the increase of TNF- $\alpha$ mRNA levels was barely observed in KO mice after $\mathrm{DMN}$ administration. These differences were statistically significant at 1 and 2 weeks $(p<0.05$ and $p<0.01$ ). In addition, MCP-1 mRNA levels were significantly reduced in KO mice compared with WT mice 1 week after DMN administration ( $p<0.05$ ). However, there were no significant differences in TGF- $\beta$ and M-CSF mRNA expression between WT and $\mathrm{KO}$ mice.

Because TNF- $\alpha$ mRNA levels were increased with similar kinetics as an increase in F4/80-positive cell number (Figs. $3 \mathrm{~g}$ and $7 \mathrm{~B}$ ), we postulated that the main sources of TNF- $\alpha$ were infiltrated F4/80-positive cells. To confirm this hypothesis, the liver sections, before or after treatment with DMN for 1 week, were double stained with anti-F4/80 and anti-TNF- $\alpha$ antibodies. As shown in Figure 8c, almost all infiltrated F4/80-positive cells and several hepatocytes expressed TNF- $\alpha$ protein in WT mice after DMN treatment. In contrast, 

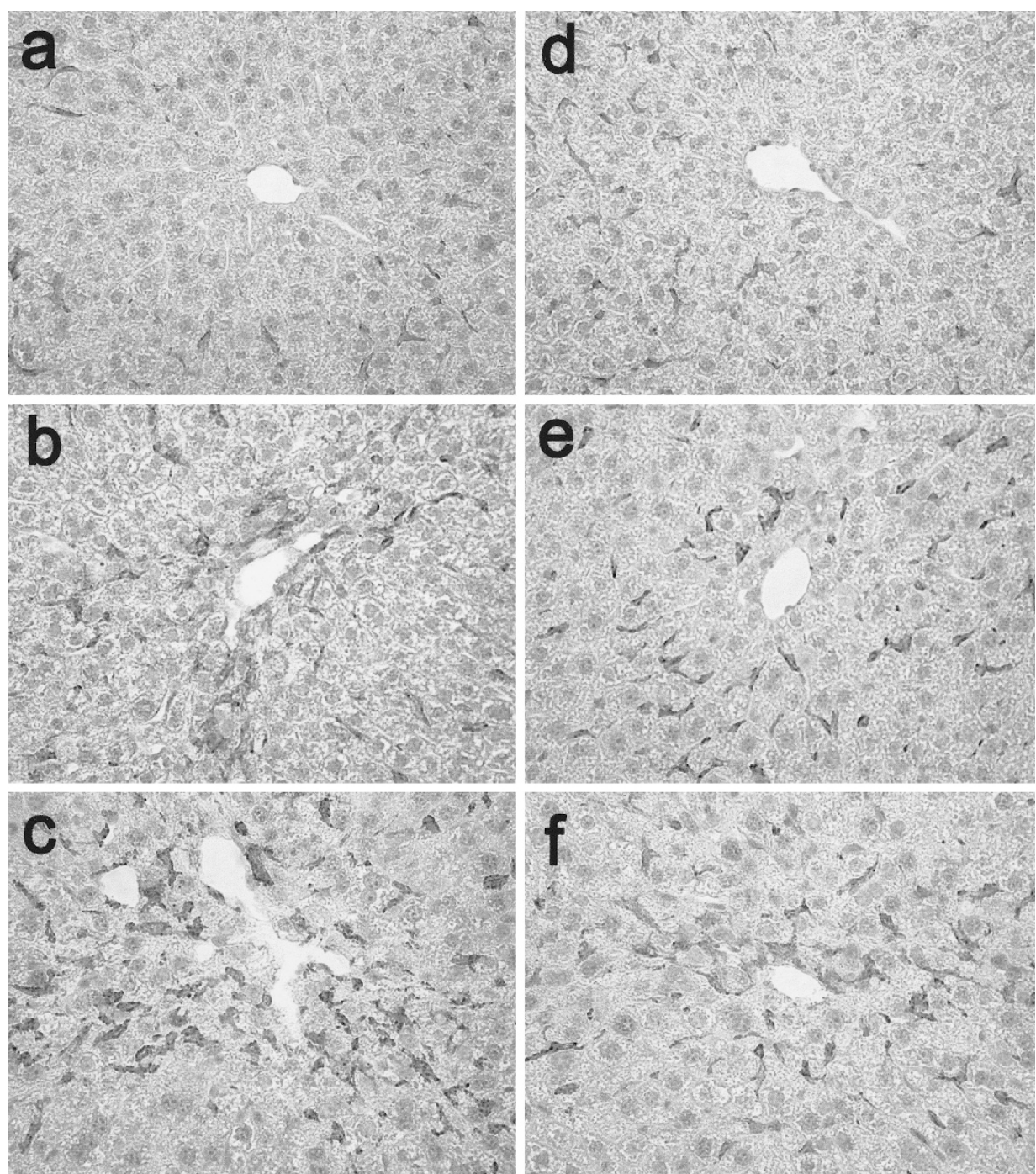

9

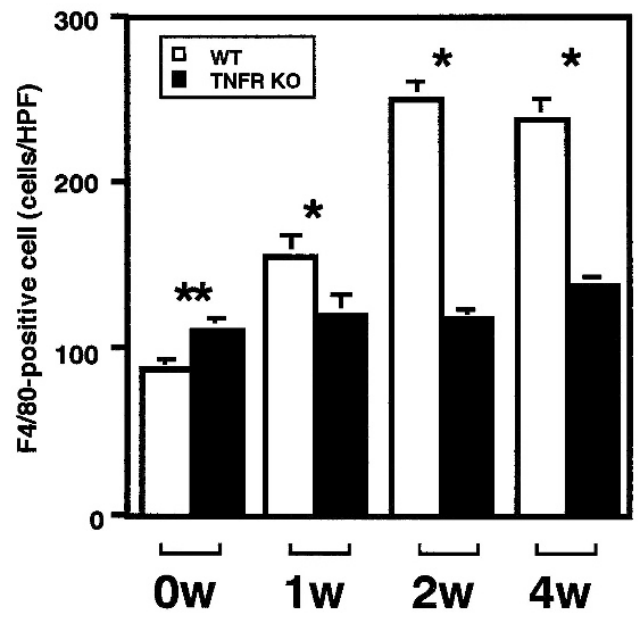

Figure 3.

Immunohistochemical detection of F4/80-positive cell in livers. a-f, Liver tissues were obtained from WT (left panels) or TNFRp55-K0 (right panels) mice before (a and $d), 1$ week after ( $b$ and e), or 4 weeks after ( $c$ and $f$ ) the initiation of DMN administration. The tissues used in Figure 1 were serially cut and immunostained with anti-mouse F4/80 antibody as described in "Materials and Methods." At least three animals were killed at each time point for immunostaining, and representative results are shown here. Original magnification, $\times 400$. g. The numbers of F4/80-positive cells were counted on 10 randomly chosen areas under a microscope at $\times 400$ magnification without prior knowledge of the experimental procedures. Results are expressed as means, and error bars indicate SEM ${ }^{*} p<0.01$; ${ }^{* *} p<0.05$. 

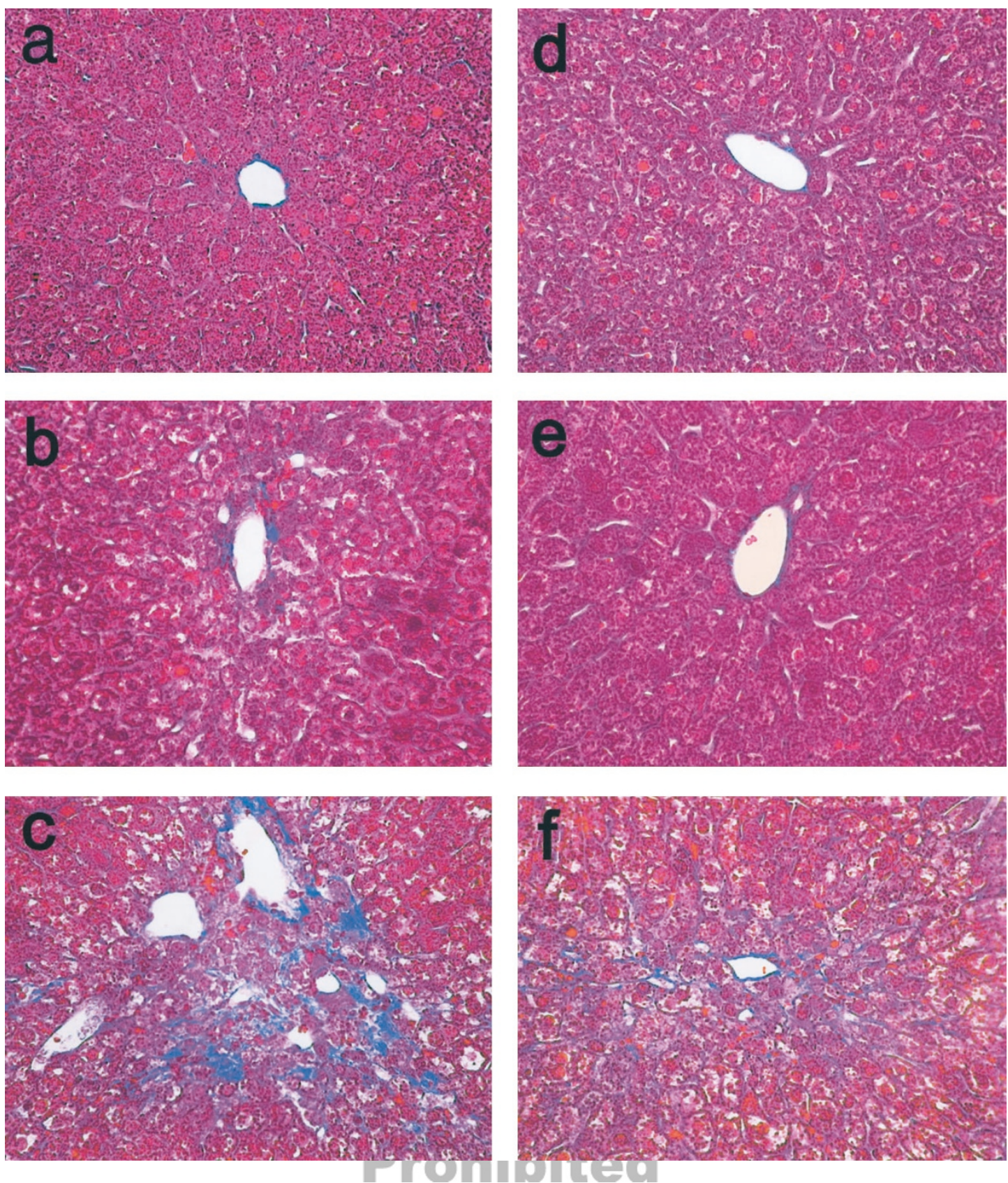

\section{Figure 4.}

Histopathologic detection of collagen in livers. Serial sections of the same tissues in Figure 1 were stained with Azan solution. Liver tissues were obtained from WT (left pane/s) or TNFRp55-K0 (right pane/s) mice before (a and d), 1 week after ( $\mathrm{b}$ and e), or 4 weeks after ( $\mathrm{c}$ and $\mathrm{f}$ ) the initiation of DMN administration. Blue coloration indicates the presence of collagen. Representative results from at least three individual animals in each group are shown here. Original magnification, $\times 400$.

scattered F4/80-positive cells were observed in $\mathrm{KO}$ mice, and only a small proportion of them expressed TNF- $\alpha$ protein (Fig. 8f). The number of F4/80 and TNF- $\alpha$ double-positive cells was significantly larger in WT mice than in KO mice 1 week after DMN administration $(p<0.01)$. Of interest is that basal expression of TNF- $\alpha$ was also significantly higher in WT mice compared with KO mice $(p<0.01)$.

\section{An Increase in HSC Number Was Attenuated in TNFRp55-KO Mice}

Because HSC was considered as a main source of extracellular matrix in liver tissues, we identified these cells in the liver by immunostaining using an antibody for $\alpha$-smooth muscle actin ( $\alpha$-SMA), a marker of activated HSC. As shown in Fig. 9, a and d, there were few $\alpha$-SMA-positive cells in the liver before DMN administration in both groups. $\alpha$-SMA-positive cells were evident 1 week after DMN injection and became more abundant after treatment with DMN for 2 and 4 weeks in WT mice. However, $\alpha$-SMA-positive cells were scarcely observed at 1 week in $\mathrm{KO}$ mice. At 2 and 4 weeks, the increase in $\alpha$-SMA-positive cell accumulation was significantly less in $\mathrm{KO}$ mice compared with WT mice, consistent with the results of Azan staining. 


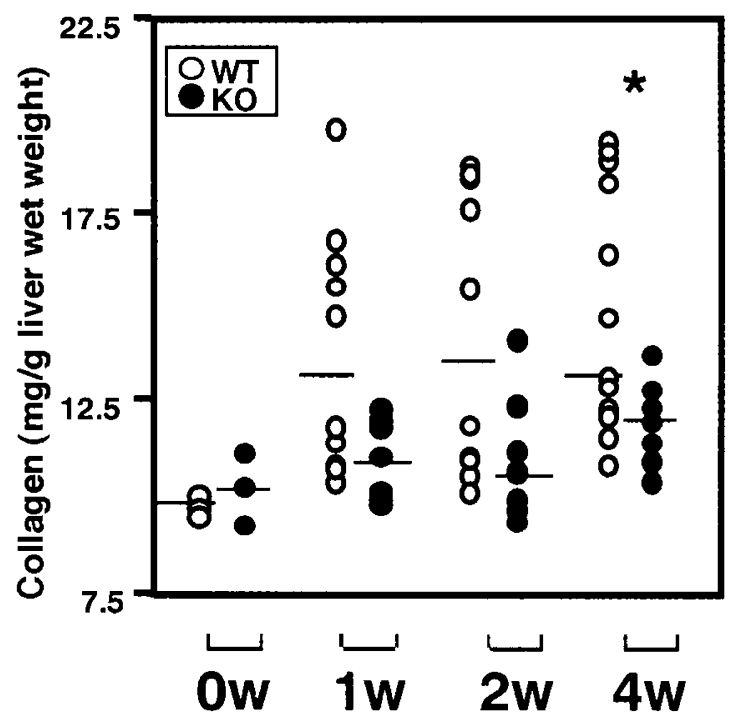

Figure 5.

Changes in intrahepatic collagen levels. WT (open circles) or TNFRp55-KO (closed circles) mice were intraperitoneally injected twice a week with DMN for the indicated time intervals. Liver collagen levels were determined as described in "Materials and Methods." Each symbol represents the value obtained from one animal, and each bar represents the median of each group. ${ }^{*} p<0.05$.

\section{Discussion}

The present study demonstrated that DMN-induced liver fibrosis was markedly attenuated in TNFRp55-KO

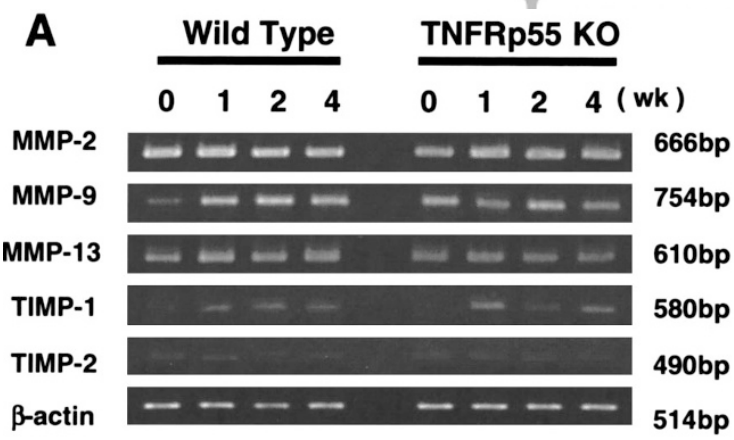

B

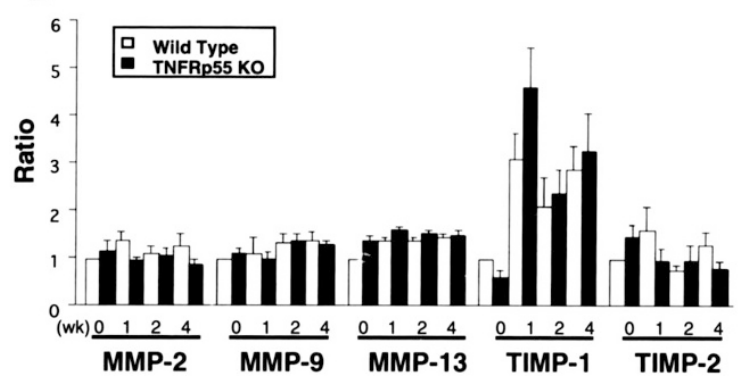

Figure 6.

Changes in gene expression of matrix metalloproteinases (MMPs) and tissue inhibitors of MMPs (TIMPs) after DMN treatment. Total RNAs were extracted from either WT or TNFRp55-KO mice before or 1, 2, and 4 weeks after treatment with DMN. RT-PCR was performed on three individual animals in each group, and representative results are shown (A). The ratio of each PCR product to $\beta$-actin was determined, and the relative intensity to untreated WT mice was calculated. Results are expressed as means, and error bars indicate SEM (B).
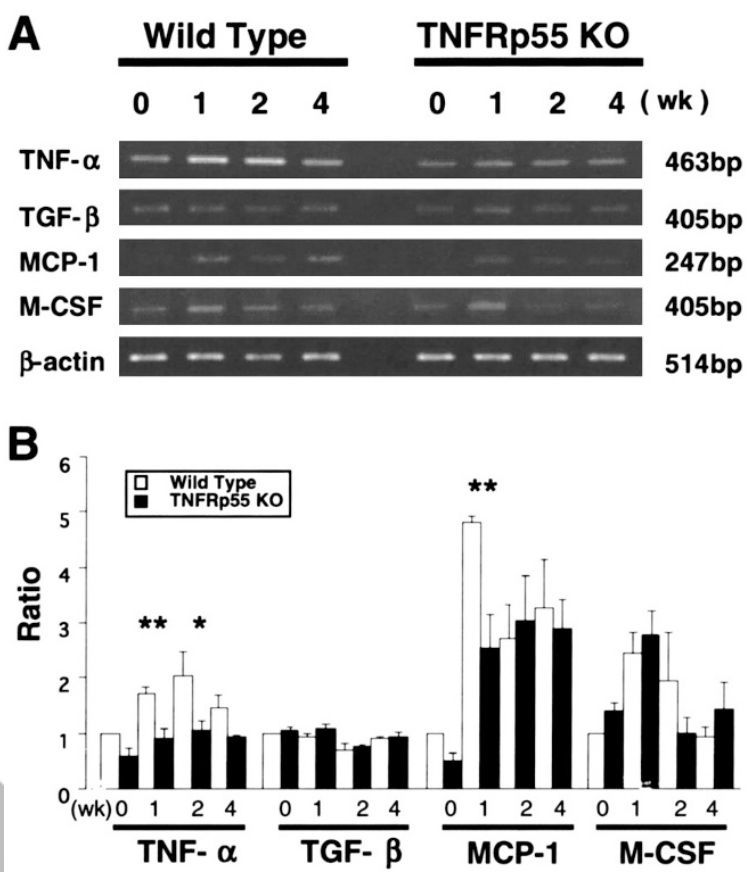

Figure 7.

Changes in cytokine or growth factor gene expression after DMN treatment. Total RNAs were extracted from either WT or TNFRp55-K0 mice before or 1, 2 , and 4 weeks after treatment with DMN. TNF- $\alpha$, transforming growth factor (TGF)- $\beta$, monocyte chemoattractant protein (MCP)-1, and macrophage (M)CSF transcripts were amplified as described in "Materials and Methods." RT-PCR was performed on three individual animals in each group, and representative results are shown (A). The ratio of each PCR product to $\beta$-actin was determined, and the relative intensity to untreated WT mice was calculated. Results are expressed as means, and error bars indicate SEM (B). * $p<0.01 ; * * p<0.05$.

mice compared with WT mice. Moreover, the numbers of Kupffer cells and the levels of TNF- $\alpha$ expression were decreased in liver tissues of TNFRp55-KO mice. Furthermore, the number of activated HSCs was reduced in TNFRp55-KO mice compared with WT mice, consistent with attenuated fibrotic changes. Thus, TNFRp55-mediated signals may play a crucial role in liver fibrosis by inducing Kupffer cell and HSC activation and eventual collagen production.

DMN is a potent hepatotoxicant, which is metabolized within hepatocytes and selectively induces hepatocyte necrosis or apoptosis (Horn et al, 2000; Pritchard and Bulter, 1989; Ueki et al, 1999). Intermittent administration of this reagent was reported to induce liver fibrosis in dogs and rats (Jenkins et al, 1985; Madden et al, 1970). In our experiment in mice, an elevation in serum ALT levels was observed in both WT and KO mice at similar levels during DMN treatment, indicating that similar levels of hepatocyte necrosis occurred in both groups. Because the previous reports suggested the signal through TNFRp55 may be essential for apoptosis of hepatocytes (Larrick and Wright, 1990), we postulated that the lack of TNFRp55-mediated signal might cause impairment in apoptosis induced by DMN administration and that reduced apoptosis might influence infiltration and activation of Kupffer cells. However, contrary to our presumption, hepatocyte apoptosis was barely de- 

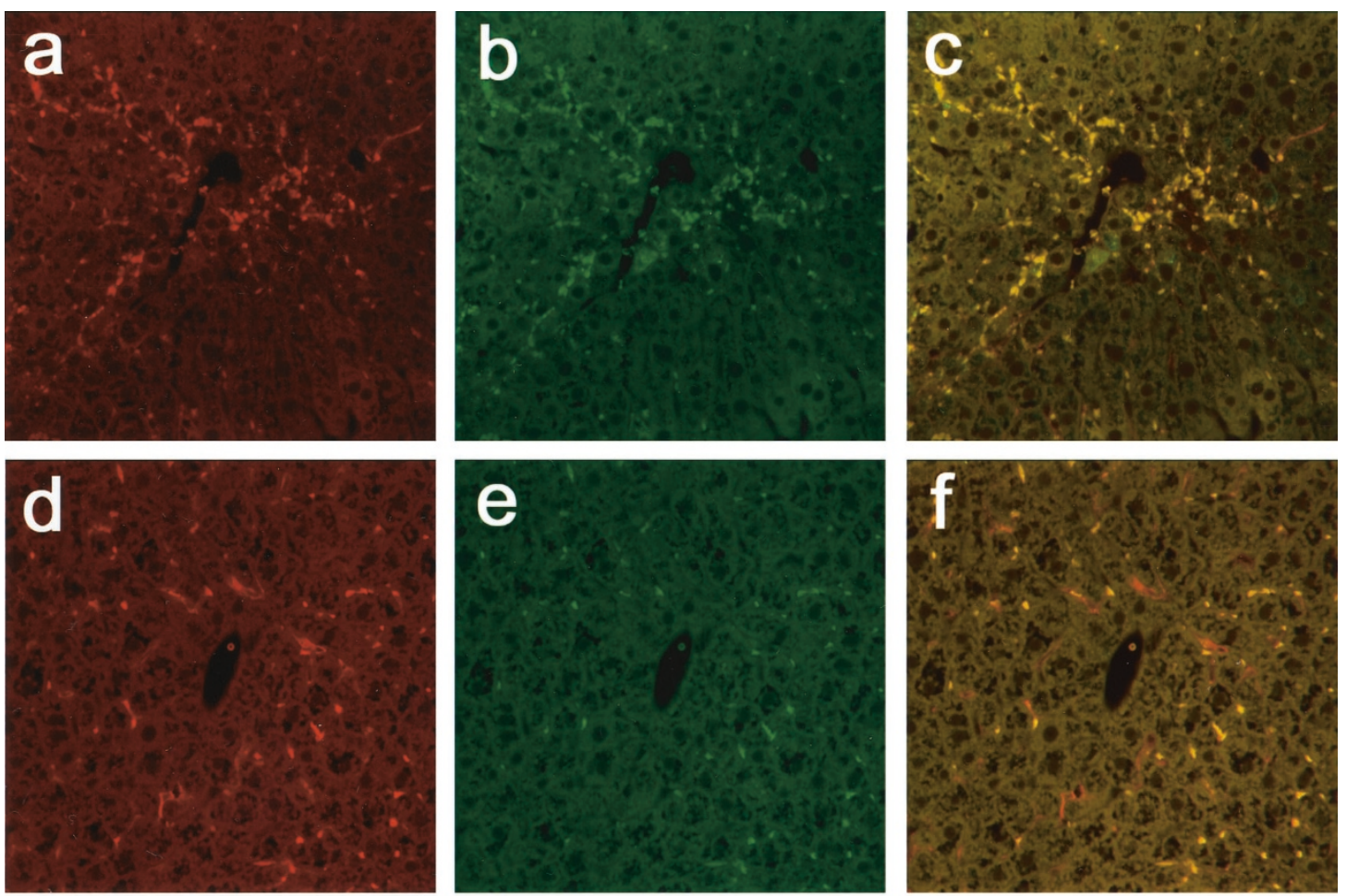

\section{g}

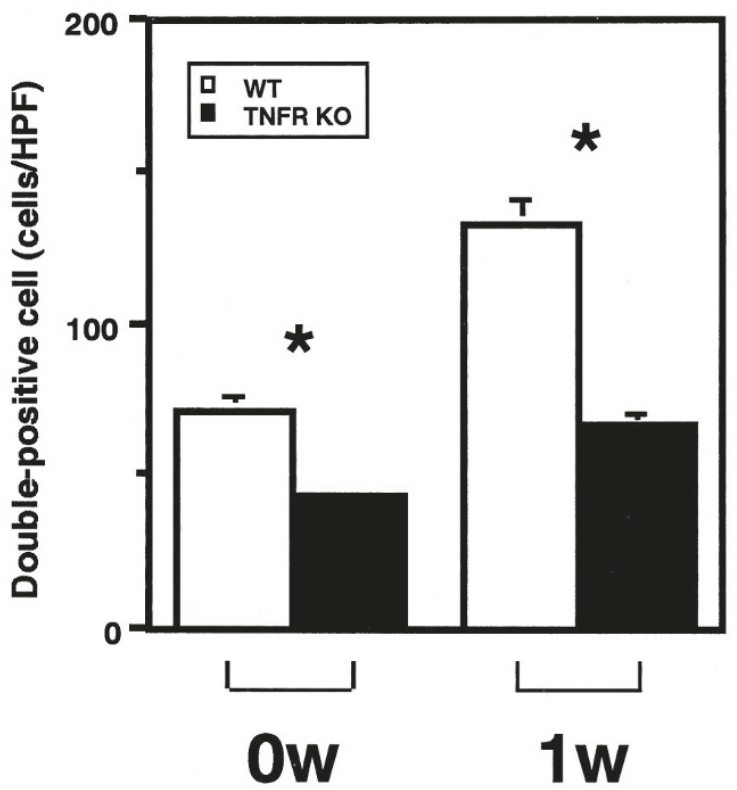

Figure 8.

Immunofluorescent staining for F4/80 and TNF- $\alpha$ after DMN treatment. A-f, Liver tissues were obtained from WT (upper panels) or TNFRp55-KO (Iower pane/s) mice before or 1 week after treatment with DMN. The sections were double stained with rat anti-mouse F4/80 and rabbit anti-mouse TNF- $\alpha$ as primary antibodies, and with donkey Cy3-anti-rat IgG and donkey FITC-anti-rabbit IgG antibodies as secondary antibodies. F4/80-positive cells were stained as red (a and d), TNF- $\alpha$-positive cells were stained as green ( $b$ and $e$ ), and double-positive cells were stained as yellow ( $c$ and $f)$. Representative results from three individual animals in each group are shown. Original magnification, $\times 400 \mathrm{~g}$, The numbers of $\mathrm{F} 4 / 80$ - and TNF- $\alpha$-double-positive cells were counted on seven randomly chosen areas under a fluorescence microscope at $\times 400$ magnification without prior knowledge of the experimental procedures. Results are expressed as means, and error bars indicate SEM ${ }^{*} p<0.01$.

tected in either mice until 48 hours after DMN administration (data not shown). These observations suggest that TNFRp55-mediated apoptosis plays a minimal, if any, role in Kupffer cell infiltration and subsequent fibrotic changes in this model.
DMN-induced fibrotic changes were associated with an increase in intrahepatic Kupffer cells, hepatic macrophages that reside in the sinusoids (Winwood and Arthur, 1993). To clarify the mechanism of Kupffer cell accumulation, we analyzed gene expression of 

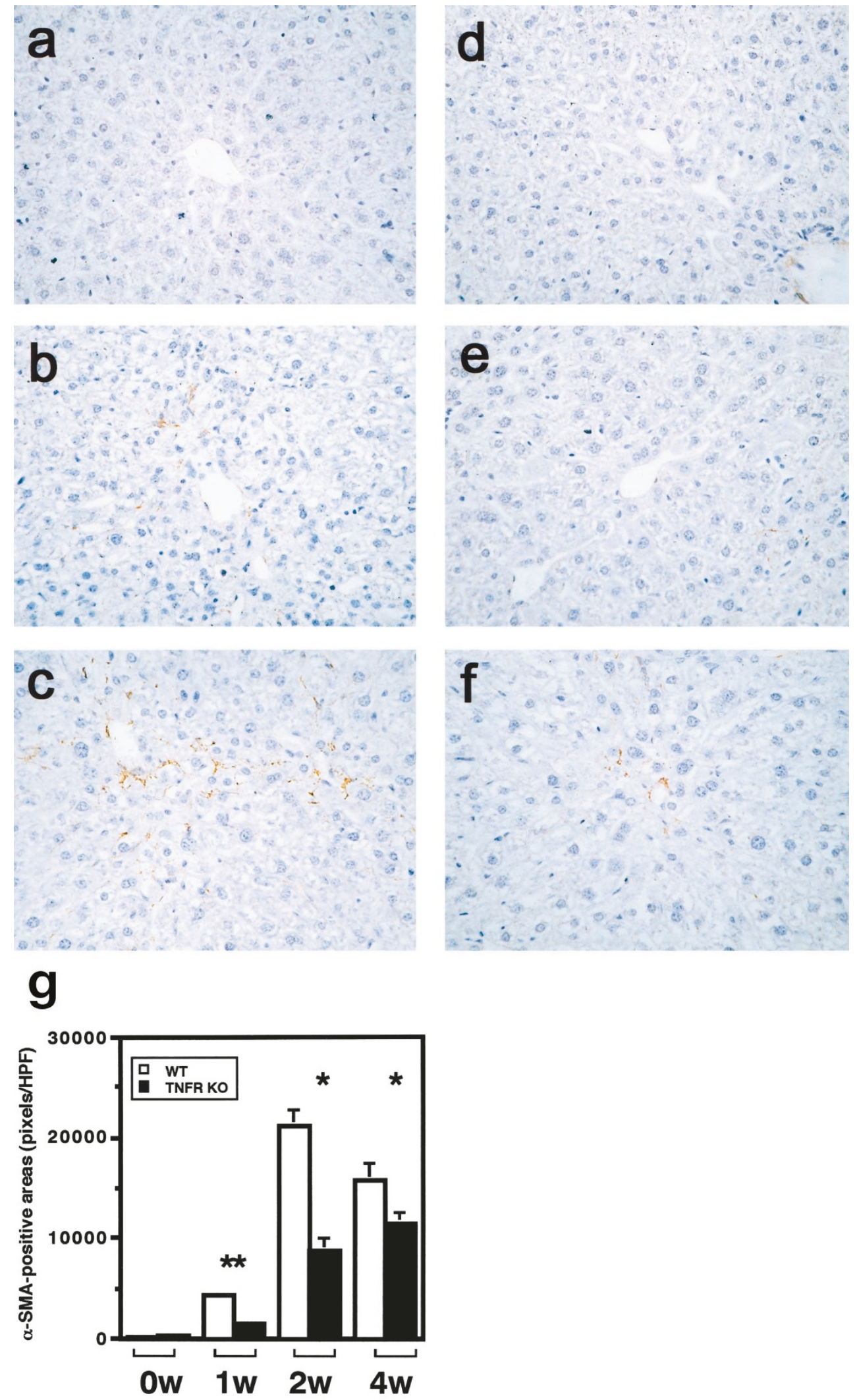

Figure 9.

Immunohistochemical detection of activated hepatic stellate cell (HSC) after DMN treatment. a-f, Serial sections of the same tissues used in Figure 1 were immunostained with anti- $\alpha$-smooth muscle actin ( $\alpha$-SMA) antibody as described in "Materials and Methods." Liver tissues were obtained from WT (left pane/s) or TNFRp55-KO (right pane/s) mice before (a and d), 1 week after ( $b$ and e), or 4 weeks after ( $c$ and f) the initiation of DMN administration. Representative results from three individual animals in each group are shown. Original magnification, $\times 400$. $\mathrm{g}$. The pixel number of $\alpha$-SMA-positive areas was calculated on five randomly chosen areas at $\times 400$ magnification with the aid of Adobe Photoshop software. Results are expressed as means, and error bars indicate SEM $^{\star} p<0.01 ;{ }^{\star \star} p<0.05$. 
several cytokines or growth factors, which are presumed to be involved in Kupffer cell activation, migration, or proliferation (Armendariz-Borunda et al, 1991; Bone-Larson et al, 2000; Naito et al, 1991; Winwood and Arthur, 1993). Among these cytokines, TNF- $\alpha$, MCP-1, and M-CSF expression was significantly enhanced in WT mice treated with DMN. In contrast, TNF- $\alpha$ and MCP-1 expression was attenuated in TNFRp55-KO mice. Several lines of evidence indicate that TNF- $\alpha$ regulates macrophage/Kupffer cell differentiation or activation and induces cytokine production from these cells in autocrine or paracrine manners (Branch and Guilbert, 1996; Haas et al, 1999; Mukhopadhyay et al, 2001; Witsell and Schook, 1992; Xie et al, 1998). Supporting this notion, an increase in F4/80positive cells kept pace with that in TNF- $\alpha$ mRNA expression. Furthermore, almost all infiltrated F4/80positive cells expressed TNF- $\alpha$ protein in WT mice treated with DMN. Thus, we postulated that Kupffer cell-derived TNF- $\alpha$ increased the number of Kupffer cells at least partly in an autocrine manner.

Chemokines regulate trafficking of various types of leukocytes into various organs, including the liver, through interaction with their specific receptors (BoneLarson et al, 2000; Luster, 1998). TNF- $\alpha$ has profound effects on expression of several chemokines, such as MCP-1 (Ueda et al, 1994, 1997). The mRNA levels of MCP-1, a potent chemokine against monocytes and macrophages (Zlotnik and Yoshie, 2000), were enhanced in livers of WT mice treated with DMN. However, increased MCP-1 expression was attenuated in KO mice compared with WT mice 1 week after DMN treatment. Thus, MCP-1 may have a role in recruiting hepatic macrophages and Kupffer cells, especially in the early phase, in this liver fibrosis model.

Activated Kupffer cells have been presumed to be a main source of MMPs and TIMPs in the liver (Goetzl et al, 1996). MMP-2, -9 , and -13 can degrade collagens, whereas TIMP-1 and -2 can inhibit their effects (Nagase and Woessner, 1999). Several lines of evidence suggest that the imbalance between MMP and TIMP activities may be involved in fibrotic changes in the liver (Iredale et al, 1998; Lichtinghagen et al, 1998; Preaux et al, 1999; Takahara et al, 1995; Yoshiji et al, 2000). However, we failed to detect any differences in MMP and TIMP mRNA expression between WT and $\mathrm{KO}$ mice during the course of DMN treatment. Although we cannot completely exclude the possibility that there are differences in enzyme activities, it is rather unlikely that MMPs and TIMPs play major roles in this liver fibrosis model.

Activated Kupffer cells are also known to produce several fibrogenic growth factors, including TGF- $\beta$ (Friedman and Arthur, 1989; Winwood and Arthur, 1993). TGF- $\beta$ can have a profibrogenic property in the liver through activating HSCs (Armendariz-Borunda et al, 1992; Border and Noble, 1994; Czaja et al, 1989; Knittel et al, 1996). However, as shown in Figure 7, TGF- $\beta$ mRNA expression was not enhanced in mice treated with DMN. Consistent with this observation, in a lung fibrosis model induced by silica, the severity of pulmonary fibrosis was not correlated with TGF- $\beta$ expression. Moreover, silica-induced lung fibrosis was markedly attenuated by anti-TNF antibody administration (Piguet et al, 1990), similar to our present DMNinduced liver fibrosis model. Furthermore, macrophage infiltration was observed inside silicotic nodules, with minimal lymphocyte infiltration in this silica-induced lung fibrosis (Piguet et al, 1990). Taken collectively, TGF- $\beta$-independent but TNF- $\alpha$-dependent pathways may have crucial roles in fibrogenesis, particularly when monocyte/macrophage infiltration is a prominent pathologic feature.

The HSCs, also termed lipocytes, fat-storing cells, or Ito cells, are presumed to promote liver fibrosis by producing extracellular matrix (Friedman, 1990, 1993). Liver injury frequently induces HSCs to transdifferentiate from quiescent cells containing retinoid droplets to activated myofibroblast-like cells. Activated HSCs express $\alpha$-SMA, vimentin, or fibronectin (Friedman, 1993; Knittel et al, 1999a). Several lines of evidence demonstrate that HSCs are activated by several cytokines or growth factors, including TNF- $\alpha$ and TGF- $\beta$ (Armendariz-Borunda et al, 1992; Czaja et al, 1989; Hellerbrand et al, 1996, 1998; Knittel et al, 1996, 1997, 1999b; Saile et al, 1999). Although TNF- $\alpha$ has also been described to down-regulate the expression of the Type I collagen genes in human fibroblasts and rat HSCs in vitro by directly antagonizing fibrogenic actions of TGF- $\beta$ at the transcriptional level (ArmendarizBorunda et al, 1992; Iraburu et al, 2000; Solis-Herruzo et al, 1988), the current observations suggest that TNF- $\alpha$-mediated and/or TNFRp55-mediated signals may contribute to the activation of HSC and eventually the promotion of fibrotic changes in the liver. Because TNF- $\alpha$ and/or TNFRp55 is involved directly in fibrosis in the lung and pancreas (Higuchi et al, 1992; Liu et al, 1998; Ortiz et al, 1998; Piguet et al, 1989, 1990), we postulate that TNF- $\alpha$ /TNFRp55-mediated signals may also be crucially involved in the pathogenesis of liver fibrosis and can be a plausible molecular target to prevent liver fibrosis.

\section{Materials and Methods}

\section{Mice}

Specific pathogen-free BALB/c mice were purchased from Charles River Japan Co. (Yokohama, Japan) and designated as WT mice. TNFRp55-KO mice were generated as described previously (Rothe et al, 1993) and backcrossed to BALB/c mice for at least six generations. All mice were female and used at the age of 8 to 12 weeks. All animal experiments were performed in accordance with the Guideline for the Care and Use of Laboratory Animals on the Takara-machi Campus of Kanazawa University.

\section{Experimental Procedures}

Mice were injected intraperitoneally with $10 \mathrm{mg} / \mathrm{kg}$ of DMN (N-nitrosodimethylamine; Nacalai Tesque Inc., Kyoto, Japan) in $0.9 \%$ physiologic saline twice a week for the indicated periods. At least five animals were killed at the indicated time points to obtain sera or liver 
tissues. Serum ALT levels were determined with a Fuji Dri-Chem 5500V (Fuji Film, Tokyo, Japan) according to the manufacturer's instructions.

\section{Quantitation of Collagen in Liver Tissue}

Liver tissues were weighed and solubilized in $0.5 \mathrm{~m}$ acetic acid. The collagen contents of the solubilized fraction were determined with a Sircol Collagen Assay Kit Dye Reagent (Biocolor Ltd., Belfast, United Kingdom) according to the manufacturer's instructions. The results are expressed as collagen (milligram) divided by tissue weight (gram).

\section{Antibodies}

For immunohistochemical analyses, the following antibodies were used as primary antibodies. Rat antimouse F4/80 monoclonal antibody was obtained from Serotec (Oxford, United Kingdom). Anti-mouse TNF- $\alpha$ polyclonal antibodies were purified from immunized rabbit serum as described previously (Sekido et al, 1993). Mouse anti- $\alpha$-SMA monoclonal antibody (clone asm-1) was obtained from Boehringer Mannheim GmbH (Mannheim, Germany). Isotype-matched IgG from each animal was used as a negative control.

\section{Histologic and Immunohistochemical Examinations}

The liver specimens were obtained at the indicated time points and fixed with 10\% neutral buffered formaldehyde. For a histologic examination, paraffinembedded sections were deparaffinized and stained with hematoxylin-eosin or Azan solution. For an immunohistochemical identification of the types of infiltrated cells, paraffin-embedded sections were deparaffinized in xylene and rehydrated through graded concentrations of ethanol. After serial treatment with $1 \%(\mathrm{v} / \mathrm{v})$ hydrogen peroxide in methanol, sections were incubated overnight at $4^{\circ} \mathrm{C}$ with anti-F4/80 antibody to detect Kupffer cells. Tissue sections were then rinsed and further incubated with biotinconjugated anti-rat $\lg G$ antibody and treated with a Vectastain Elite ABC Kit (Vector, Burlingame, California) according to the manufacturer's instructions. The slides were then reacted with a Vectastain DAB Substrate Kit (Vector) and counterstained with hematoxylin. For an immunohistochemical staining of activated HSCs, DAKO Envision System (DAKO, Carpinteria, California) combined with mouse anti- $\alpha$-SMA antibody was used according to the manufacturer's instructions. In brief, the liver sections were incubated with the polymer immunocomplex (which consisted of primary antibody and peroxidase-labeled polymerconjugated goat anti-mouse IgG antibody) for 1 hour and reacted with DAB substrate. For immunofluorescence analysis, the sections treated with rat antimouse F4/80 and rabbit anti-mouse TNF- $\alpha$ antibodies were subsequently incubated with donkey $\mathrm{Cy} 3$ anti-rat $\lg G$ antibody and donkey FITC anti-rabbit IgG antibody and examined under a fluorescence microscope. The data was analyzed with the aid of Adobe Photoshop software (version 4.0J; Adobe Systems Inc., San Jose, California).

\section{RNA Isolation and Semiquantitative RT-PCR}

Total RNA was isolated from a part of the liver tissues with RNAzol B (Biotex Laboratory Inc., Houston, Texas) according to the manufacturer's instructions, and CDNA was synthesized as described previously (Natsume et al, 1999). Thereafter, cDNA was amplified using sets of primers that specifically amplify mouse MMP, TIMP, and several cytokines and growth factors (Table 1). The amplified PCR products were fractionated on a $2 \%$ agarose gel and visualized by ethidium bromide. The intensities of the bands were measured with the aid of NIH Image Analysis software (version 1.62; National Institutes of Health, Bethesda, Mary(land), and the ratios to $\beta$-actin were determined. The relative intensities were calculated on the assumption that the ratio of the untreated wild-type mice was 1.00 .

\section{Statistical Analysis}

Statistical significance on the serum ALT and tissue collagen levels was analyzed by the Mann-Whitney $U$ test. Infiltrated cell number, $\alpha$-SMA-positive area, and relative intensities of PCR products were analyzed

Table 1. Sequences of the Primers and Conditions of PCR

\begin{tabular}{|c|c|c|c|c|c|}
\hline & Sense primer & Antisense primer & Annealing & Cycles & $\begin{array}{l}\text { Product } \\
\text { (bp) }\end{array}$ \\
\hline MMP-2 & GAGTTGGCAGTGCAATACCT & GCCGTCCTTCTCAAAGTTGT & $55^{\circ} \mathrm{C}, 1 \mathrm{~min}$ & 40 & 666 \\
\hline MMP-9 & AGTTTGGTGTCGCGGAGCAC & TACATGAGCGCTTCCGGCAC & $55^{\circ} \mathrm{C}, 1 \mathrm{~min}$ & 40 & 754 \\
\hline MMP-13 & CTGGTCTTCTGGCACACGCT & GCAGCGCTCAGTCTCTTCAC & $55^{\circ} \mathrm{C}, 1 \mathrm{~min}$ & 40 & 610 \\
\hline TIMP-1 & CTGGCATCCTCTTGTTGCTA & AGGGATCTCCAGGTGCACAA & $55^{\circ} \mathrm{C}, 1 \mathrm{~min}$ & 40 & 580 \\
\hline TIMP-2 & AGACGTAGTGATCAGGGCCA & GTACCACGCGCAAGAACCAT & $60^{\circ} \mathrm{C}, 30 \mathrm{sec}$ & 40 & 490 \\
\hline TNF- $\alpha$ & AGTTCTATGGCCCAGACCCT & CGGACTCCGCAAAGTCTAAG & $55^{\circ} \mathrm{C}, 1 \mathrm{~min}$ & 32 & 463 \\
\hline TGF- $\beta$ & CGGGGCGACCTGGGCACCATCCATGAC & CTGCTCCACCTTGGGCTTGCGACCCAC & $60^{\circ} \mathrm{C}, 30 \mathrm{sec}$ & 30 & 405 \\
\hline MCP-1 & AAGCCAGCTCTCTCTTCCTC & ССTCTCTCTTGAGCTTGGTG & $59^{\circ} \mathrm{C}, 30 \mathrm{sec}$ & 32 & 247 \\
\hline M-CSF & СCTGTGTCCGAACTTTCCAT & TTGGTTGCTCTGTTGACTCG & $55^{\circ} \mathrm{C}, 1 \mathrm{~min}$ & 32 & 405 \\
\hline$\beta$-actin & TGTGATGGTGGGAATGGGTCAG & TTTGATGTCACGCACGATTTCC & $55^{\circ} \mathrm{C}, 1 \mathrm{~min}$ & 25 & 514 \\
\hline
\end{tabular}

MMP, matrix metalloproteinase; TIMP, tissue inhibitor of MMP; TGF, transforming growth factor; MCP, monocyte chemoattractant protein; M-CSF, macrophage-CSF. 
using ANOVA followed by the Fisher's protected least significant difference test. $P$ values less than 0.05 were considered statistically significant.

\section{References}

Armendariz-Borunda J, Katayama K, and Seyer JM (1992). Transcriptional mechanisms of type I collagen gene expression are differentially regulated by interleukin- $1 \beta$, tumor necrosis factor $\alpha$, and transforming growth factor $\beta$ in Ito cells. J Biol Chem 267:14316-14321.

Armendariz-Borunda J, Seyer JM, Postlethwaite AE, and Kang AH (1991). Kupffer cells from carbon tetrachlorideinjured rat livers produce chemotactic factors for fibroblasts and monocytes: The role of tumor necrosis factor- $\alpha$. Hepatology 14:895-900.

Beutler B and Cerami A (1986). Cachectin and tumor necrosis factor as two sides of the same biological coin. Nature 320:584-588.

Bone-Larson CL, Simpson KJ, Colletti LM, Lukacs NW, Chen SC, Lira S, Kunkel SL, and Hogaboam CM (2000). The role of chemokines in the immunopathology of the liver. Immunol Rev 177:8-20.

Border WA and Noble NA (1994). Transforming growth factor $\beta$ in tissue fibrosis. N Engl J Med 331:1286-1292.

Branch DR and Guilbert LJ (1996). Autocrine regulation of macrophage proliferation by tumor necrosis factor- $\alpha$. Exp Hematol 24:675-681.

Bruccoleri A, Gallucci R, Germolec DR, Blackshear P, Simeonova P, Thurman RG, and Luster MI (1997). Induction of early-immediate genes by tumor necrosis factor $\alpha$ contribute to liver repair following chemical-induced hepatotoxicity. Hepatology 25:133-141.

Czaja MJ, Weiner FR, Flanders KC, Giambrone MA, Wind R, Biempica L, and Zern MA (1989). In vitro and in vivo association of transforming growth factor- $\beta 1$ with hepatic fibrosis. J Cell Biol 108:2477-2482.

Czaja MJ, Xu J, and Alt E (1995). Prevention of carbon tetrachloride-induced rat liver injury by soluble tumor necrosis factor receptor. Gastroenterology 108:1849-1854.

Friedman SL (1990). Cellular sources of collagen and regulation of collagen production in liver. Semin Liver Dis 10:2029.

Friedman SL (1993). The cellular basis of hepatic fibrosis. N Engl J Med 328:1828-1835.

Friedman SL (2000). Molecular regulation of hepatic fibrosis, an integrated cellular response to tissue injury. J Biol Chem 275:2247-2250.

Friedman SL and Arthur MJP (1989). Activation of cultured rat hepatic lipocytes by Kupffer cell conditioned medium: Direct enhancement of matrix synthesis and stimulation of cell proliferation via induction of platelet-derived growth factor receptors. J Clin Invest 84:1780-1785.

Goetzl EJ, Banda MJ, and Leppert D (1996). Matrix metalloproteinases in immunity. J Immunol 156:1-4.

Haas E, Grell M, Wajant H, and Scheurich P (1999). Continuous autotropic signaling by membrane-expressed tumor necrosis factor. J Biol Chem 274:18107-18112.

Hellerbrand C, Jobin C, Licato LL, Sartor RB, and Brenner DA (1998). Cytokine induced NF- $\mathrm{B}$ in activated but not in quiescent rat hepatic stellate cells. Am J Physiol 275:G269_ G278.

Hellerbrand C, Wang SC, Tsukamoto H, Brenner DA, and Rippe RA (1996). Expression of intercellular adhesion molecule 1 by activated hepatic stellate cells. Hepatology 24:670676.

Higuchi Y, Herrera P, Muniesa P, Huarte J, Belin D, Ohashi P, Aichele P, Orci L, Vassalli JD, and Vassalli P (1992). Expression of a tumor necrosis factor $\alpha$ transgene in murine pancreatic $\beta$ cells results in severe and permanent insulitis without evolution towards diabetes. J Exp Med 176:17191731.

Horn TL, O'Brien TD, Schook LB, and Rutherford MS (2000). Acute hepatotoxicant exposure induces TNFR-mediated hepatic injury and cytokine/apoptosis gene expression. Toxicol Sci 54:262-273.

limuro Y, Gallucci RM, Luster MI, Kono H, and Thurman RG (1997). Antibodies to tumor necrosis factor alpha attenuate hepatic necrosis and inflammation caused by chronic exposure to ethanol in the rat. Hepatology 26:1530-1537.

Iraburu MJ, Dominguez-Rosales JA, Fontana L, Auster A, Garcia-Trevijano ER, Covarrubias-Pinedo A, Rivas-Estilla AM, Greenwel P, and Rojkind M (2000). Tumor necrosis factor $\alpha$ down-regulates expression of the $\alpha 1$ (I) collagen gene in rat hepatic stellate cells through a p20C/EBP $\beta$ - and C/EBP $\delta$-dependent mechanism. Hepatology 31:1086-1093. Iredale JP, Benyon RC, Pickering J, McCullen M, Northrop M, Pawley S, Hovell C, and Arthur MJ (1998). Mechanisms of spontaneous resolution of rat liver fibrosis: Hepatic stellate cell apoptosis and reduced hepatic expression of metalloproteinase inhibitors. J Clin Invest 102:538-549.

Jenkins SA, Grandison A, Baxter JN, Day DW, Taylor I, and Shields $R$ (1985). A dimethylnitrosamine-induced model of cirrhosis and portal hypertension in the rat. J Hepatol 1:489499.

Kanaly ST, Nashleanas M, Hondowicz B, and Scott P (1999). TNF receptor p55 is required for elimination of inflammatory cells following control of intracellular pathogens. J Immunol 163:3883-3889.

Knittel T, Dinter C, Kobold D, Neubauer K, Mehde M, Eichhorst S, and Ramadori G (1999b). Expression and regulation of cell adhesion molecules by hepatic stellate cells (HSC) of rat liver. Am J Pathol 154:153-167.

Knittel T, Janneck T, Muller L, Fellmer P, and Ramadri G (1996). Transforming growth factor $\beta 1$-regulated gene expression of Ito cells. Hepatology 24:352-360.

Knittel T, Kobold D, Saile B, Grundmann A, Neubauer K, Piscaglia F, and Ramadori G (1999a). Rat liver myofibroblasts and hepatic stellate cells: Different cell populations of the fibroblast lineage with fibrogenic potential. Gastroenterology 117:1205-1221.

Knittel T, Muller L, Saile B, and Ramadori G (1997). Effect of tumor necrosis factor- $\alpha$ on proliferation, activation and protein synthesis of rat hepatic stellate cells. J Hepatol 27:10671080.

Larrick JW and Wright SC (1990). Cytotoxic mechanism of tumor necrosis factor- $\alpha$. FASEB J 4:3215-3223.

Leist M, Gantner F, Jilg S, and Wendel A (1995). Activation of the $55 \mathrm{kDa}$ TNF receptor is necessary and sufficient for TNF-induced liver failure, hepatocyte apoptosis, and nitrite release. J Immunol 154:1307-1316. 
Leist M, Gantner F, Naumann H, Bluethmann H, Vogt K, Brigelius-Flohe R, Nicotera P, and Volk HD, Wendel A (1997). Tumor necrosis factor-induced apoptosis during the poisoning of mice with hepatotoxins. Gastroenterology 112:923934.

Lewis M, Tartaglia LA, Lee A, Bennett GL, Rice GC, Wong GHW, Chen EY, and Goeddel DV (1991). Cloning and expression of CDNAs for two distinct murine tumor necrosis factor receptors demonstrate one receptor is species specific. Proc Natl Acad Sci USA 88:2830-2834.

Lichtinghagen R, Breitenstein K, Arndt B, Kuhbacher T, and Boker KHW (1998). Comparison of matrix metalloproteinase expression in normal and cirrhotic human liver. Virchows Arch 432:153-158.

Liu JY, Brass DM, Hoyle GW, and Brody AR (1998). TNF- $\alpha$ receptor knockout mice are protected from the fibroproliferative effects of inhaled asbestos. Am J Pathol 153:1839-1847.

Llorente L, Richaud-Patin Y, Alcocer-Castillejos N, Ruiz-Soto R, Mercado MA, Orozco H, Gamboa-Dominguez A, and Alcocer-Varela J (1996). Cytokine gene expression in cirrhotic and non-cirrhotic human liver. J Hepatol 24:555-563.

Luster AD (1998). Chemokines: Chemotactic cytokines that mediate inflammation. N Engl J Med 338:436-445.

Madden JW, Gertman PM, and Peacock EE Jr (1970). Dimethylnitrosamine-induced hepatic cirrhosis: A new canine model of an ancient human disease. Surgery 68:260-268.

Mukhopadhyay A, Suttles J, Stout RD, and Aggarwal BB (1912). (2001) Genetic deletion of the tumor necrosis factor receptor p60 or p80 abrogates ligand-mediated activation of nuclear factor- $\kappa \mathrm{B}$ and of mitogen-activated protein kinases in macrophages. J Biol Chem 276:31906-1903.

Nagase $\mathrm{H}$ and Woessner JF Jr (1999). Matrix metalloproteinases. J Biol Chem 274:21491-21494.

Naito M, Hayashi S, Yoshida H, Nishikawa S, Shultz LD, and Takahashi K (1991). Abnormal differentiation of tissue macrophage populations in 'osteopetrosis' (op) mice defective in the production of macrophage colony-stimulating factor. Am J Pathol 139:657-667.

Napoli J, Bishop GA, and McCaughan GW (1994). Increased intrahepatic messenger RNA expression of interleukins 2, 6, and 8 in human cirrhosis. Gastroenterology 107:789-798.

Natsume M, Tsuji H, Harada A, Akiyama M, Yano T, Ishikura H, Nakanishi I, Matsushima K, Kaneko S, and Mukaida N (1999). Attenuated liver fibrosis and depressed serum albumin levels in carbon tetrachloride-treated IL-6-deficient mice. $\mathrm{J}$ Leukoc Biol 66:601-608.

Ortiz LA, Lasky J, Hamilton RF, Holian A, Hoyle GW, Banks W, Peschon JJ, Brody AR, Lungarella G, and Friedman M (1998). Expression of TNF and the necessity of TNF receptors in bleomycin-induced lung injury in mice. Exp Lung Res 24:721-743.

Peschon JJ, Torrance DS, Stocking KL, Glaccum MB, Otten $\mathrm{C}$, Willis $\mathrm{CR}$, Charrier K, Morrissey PJ, Ware CB, and Mohler KM (1998). TNF receptor-deficient mice reveal divergent roles for p55 and p75 in several models of inflammation. J Immunol 160:943-952.

Piguet PF, Collart MA, Grau GE, Kapanci Y, and Vassalli P (1989). Tumor necrosis factor/cachectin plays a key role in bleomycin-induced pneumopathy and fibrosis. J Exp Med 170:655-663.
Piguet PF, Collart MA, Grau GE, Sappino AP, and Vassalli P (1990). Requirement of tumor necrosis factor for development of silica-induced pulmonary fibrosis. Nature 344:245247.

Preaux A-M, Mallat A, van Nhieu JT, D'Ortho M-P, Hembry $\mathrm{RM}$, and Mavier P (1999). Matrix metalloproteinase-2 activation in human hepatic fibrosis regulation by cell-matrix interactions. Hepatology 30:944-950.

Pritchard DJ and Bulter WH (1989). Apoptosis: The mechanism of cell death in dimethylnitrosamine-induced hepatotoxicity. J Pathol 158:253-260.

Rothe J, Lesslauer W, Lotscher H, Lang Y, Koebel P, Kontgen $F$, Althage $A$, Zinkernagel $R$, Steinmetz $M$, and Bluethmann $H$ (1993). Mice lacking the tumour necrosis factor receptor 1 are resistant to TNF-mediated toxicity but highly susceptible to infection by Listeria monocytogenes. Nature 364:798-802.

Saile B, Matthes N, Knittel T, and Ramadori G (1999). Transforming growth factor $\beta$ and tumor necrosis factor $\alpha$ inhibit both apoptosis and proliferation of activated rat hepatic stellate cells. Hepatology 30:196-202.

Sekido N, Mukaida N, Harada A, Nakanishi I, Watanabe Y, and Matsushima K (1993). Prevention of lung reperfusion injury in rabbits by a monoclonal antibody against interleukin-8. Nature 365:654-657.

Sherlock S and Dooley J (1997). Hepatic cirrhosis, 10th ed. In: Disease of the liver and biliary system. Oxford: Backwell Science Ltd., 371-384.

Solis-Herruzo JA, Brenner DA, and Chojkier M (1988). Tumor necrosis factor $\alpha$ inhibits collagen gene transcription and collagen synthesis in cultured human fibroblasts. $\mathrm{J}$ Biol Chem 263:5841-5845.

Takahara T, Furui K, Funaki J, Nakayama Y, Itoh H, Miyabayashi C, Sato H, Seiki M, Ooshima A, and Watanabe A (1995). Increased expression of matrix metalloproteinase-II in experimental liver fibrosis in rats. Hepatology 21:787-795.

Takehara T, Hayashi N, Mita E, Kanto T, Tatsumi T, Sasaki Y, Kasahara A, and Hori M (1998). Delayed Fas-mediated hepatocyte apoptosis during liver regeneration in mice: Hepatoprotective role of TNF $\alpha$. Hepatology 27:1643-1651.

Tartaglia LA, Weber RF, Figari IS, Reynolds C, Palladino MA, and Goeddel DV (1991). The two different receptors for tumor necrosis factor mediate distinct cellular responses. Proc Natl Acad Sci USA 88:9292-9296.

Tilg H, Wilmer A, Vogel W, Herold M, Nolchen B, Judmaier G, and Huber $C$ (1992). Serum levels of cytokines in chronic liver diseases. Gastroenterology 103:264-274.

Tsuji H, Harada A, Mukaida N, Nakanuma Y, Bluethmann H, Kaneko S, Yamakawa K, Nakamura SI, Kobayashi KI, and Matsushima K (1997). Tumor necrosis factor receptor p55 is essential for intrahepatic granuloma formation and hepatocellular apoptosis in a murine model of bacterium-induced fulminant hepatitis. Infect Immun 65:1892-1898.

Ueda A, Ishigatsubo Y, Okubo T, and Yoshimura T (1997). Transcriptional regulation of the human monocyte chemoattractant protein-1 gene. J Biol Chem 272:31092-31099. 
Ueda A, Okuda K, Ohno S, Shirai A, Igarashi T, Matsunaga K, Fukushima J, Kawamoto S, Ishigatsubo Y, and Okubo T (1994). NF- $\kappa \mathrm{B}$ and Sp1 regulate transcription of the human monocyte chemoattractant protein-1 gene. J Immunol 153: 2052-2063.

Ueki T, Kaneda Y, Tsutsui H, Nakanishi K, Sawa Y, Morishita R, Matsumoto K, Nakamura T, Takahashi H, Okamoto E, and Fujimoto J (1999). Hepatocyte growth factor gene therapy of liver cirrhosis in rats. Nat Med 5:226-230.

Winwood PJ and Arthur MJP (1993). Kupffer cells: Their activation and role in animal models of liver injury and human liver disease. Semin Liver Dis 13:50-59.

Witsell AL and Schook LB (1992). Tumor necrosis factor $\alpha$ is an autocrine growth regulator during macrophage differentiation. Proc Natl Acad Sci USA 89:4754-4758.

Xie B, Laouar A, and Huberman E (1998). Autocrine regulation of macrophage differentiation and $92-k D a$ gelatinase production by tumor necrosis factor- $\alpha$ via $\alpha_{5 \beta 1}$ integrin in HL-60 cells. J Biol Chem 273:11583-11588.

Yamada $Y$ and Fausto $N$ (1998). Deficient liver regeneration after carbon tetrachloride injury in mice lacking type 1 but not type 2 tumor necrosis factor receptor. Am J Pathol 152: 1577-1589.
Yamada Y, Webber EM, Kirillova I, Peschon JJ, and Fausto N (1998). Analysis of liver regeneration in mice lacking type 1 or type 2 tumor necrosis factor receptor: Requirement for type 1 but not type 2 receptor. Hepatology 28:959-970.

Yin M, Wheeler MD, Kono H, Bradford BU, Gallucci RM, Luster MI, and Thurman RG (1999). Essential role of tumor necrosis factor $\alpha$ in alcohol-induced liver injury in mice. Gastroenterology 117:942-952.

Yoshiji H, Kuriyama S, Miyamoto Y, Thorgeirsson UP, Gomez DE, Kawata M, Yoshii J, Ikenaka Y, Noguchi R, Tsujinoue H, Nakatani T, Thorgeirsson SS, and Fukui H (2000). Tissue inhibitor of metalloproteinases-1 promotes liver fibrosis development in a transgenic mouse model. Hepatology 32 : 1248-1254.

Zlotnik A and Yoshie O (2000). Chemokines: A new classification system and their role in immunity. Immunity 12:121127.
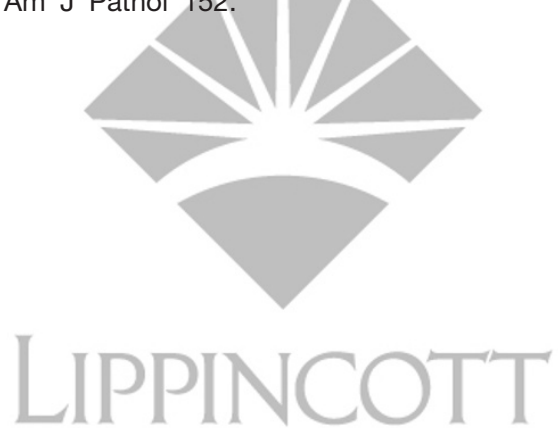

WILLIAMS \& WILKINS

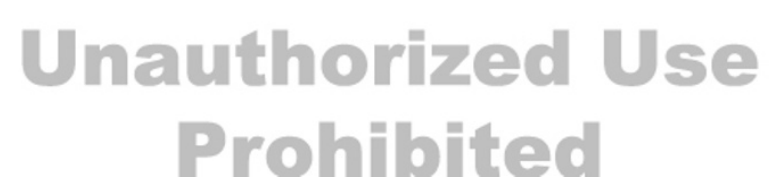

